\title{
Aplikasi FindKos Berbasis iOS
}

\author{
Calista Bertha Rucita, Prihatin Oktivasari \\ Program Studi Teknik Informatika \\ Politeknik Negeri Jakarta \\ Depok- Indonesia \\ calista.bertha@mhsw.pnj.ac.id, Prihatin.oktivasari@tik.pnj.ac.id
}

Diterima: 4 Maret 2016. Disetujui: 15 April 2016. Dipublikasikan: Mei 2016

\begin{abstract}
Abstrak - Penggunaan aplikasi berbasis mobile sangat menguntungkan di era modern seperti ini terutama dalam mencari informasi suatu tempat. Seperti contohnya dalam pencarian Indekos di daerah Depok, kebanyakan masih dilakukan oleh mahasiswa maupun karyawan secara manual. Oleh karena itu diperlukan suatu aplikasi yang dapat memberikan informasi indekost serta petunjuk arah sampai ke tempat lokasi. Findkos merupakan solusi yang menggunakan Google Maps API yang akan menampilkan peta sebagai petunjuk arah dan tersedia dalam platform iOS. Aplikasi ini menampilkan detail informasi seperti harga kamar, fasilitas yang disediakan, nomor telepon pemilik indekos yang langsung dapat dihubungi tanpa mengetik ulang, dan terdapat petunjuk arah langsung menuju lokasi. Metode yang digunakan dalam aplikasi ini dalah metode prototype. Pengujian beta dilakukan terhadap 30 responden. Dapat disimpulkan bahwa aplikasi FindKos telah berjalan dengan baik di iOS 7 sampai iOS 9.3.
\end{abstract}

Kata Kunci: indekost; Google Maps API; iOS

\section{I.PENDAHULUAN}

Depok merupakan salah satu kota yang terletak di Jawa Barat yang memiliki beberapa universitas dan politeknik seperti contohnya Universitas Indonesia dan Politeknik Negeri Jakarta. Menurut BPS kota Depok, dengan banyaknya universitas dan politeknik yang berada di kota Depok, membuat jumlah mahasiswa yang tinggal di kota tersebut terus meningkat setiap tahunnya. Hal ini didukung dengan data statistik yang dimiliki BPS sampai tahun 2015. Selain itu tidak hanya mahasiswa, kota Depok yang berada di perbatasan antara Bogor dan Jakarta pun membuat banyak karyawan juga bertempat tinggal di kota tersebut.

Seperti yang dikutip dari Okezone.com bahwa dengan banyaknya universitas dan politeknik yang berada di Depok, membuat mahasiswa yang akan berkuliah di tempat tersebut membutuhkan indekost sebagai tempat tinggal sementara ketika kampus tujuan jauh dari rumah orang tua. Tak jarang mahasiswa perlu mencari indekost yang memiliki jarak tidak jauh dari lokasi kampus dengan mencari informasi dari mulut ke mulut. Terutama bagi mereka yang tidak tinggal di kota Depok. Hal ini didukung dengan survei yang dilakukan penulis kepada 30 responden dengan mengajukan pertanyaan "Bagaimana cara Anda untuk mencari indekost di Depok?"

Seperti yang dikutip dari Kompas.com bahwa perkembangan teknologi yang sangat cepat telah membawa manusia memasuki kehidupan yang berdampingan dengan informasi dan telah membuka jalan baru bagi manusia untuk memenuhi kebutuhannya akan informasi. Didukung pula dengan berkembangnya teknologi mobile yang menjadi salah satu sarana untuk memenuhi kebutuhan tersebut. Hampir semua kalangan masyarakat memiliki telepon seluler yang mereka gunakan untuk berkomunikasi lewat suara, memeriksa email atau manfaat teknologi lainnya. Hal ini didukung dengan survei yang dilakukan oleh CNN Indonesia dimana sebanyak $85 \%$ penduduk Indonesia menggunakan telepon seluler untuk mengakses internet dan $18 \%$ dari pengguna aktif telepon seluler diduduki oleh mahasiswa. Menurut data yang dikutip dari teknoup.com, sebanyak 44,19\% pengguna iPhone lebih aktif menggunakan telepon selulernya untuk mencari informasi dan $25 \%$ pengguna diantaranya adalah mahasiswa. Data ini didapat dari hasil pengamatan di 40.000 situs yang dapat menganalisis perangkat yang pengguna gunakan untuk membuka situs yang bersangkutan.

Berdasarkan data yang telah dipaparkan sebelumnya dimana banyak mahasiswa yang masih melakukan pencarian indekost dengan bertanya dari mulut ke mulut maka dibuatlah sebuah aplikasi pencarian indekost yang diberi nama FindKos. Aplikasi ini merupakan pengembangan dari aplikasi terdahulunya yaitu KukelKos. 


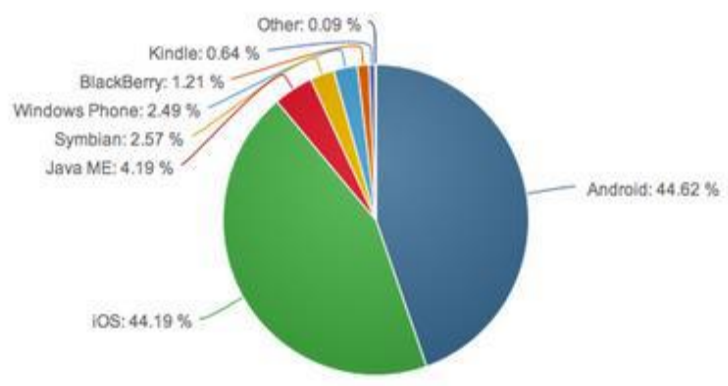

Gambar 1. Perbandingan Pengguna IOS dan OS Lainnya

Perbedaannya adalah adanya penambahan area pada aplikasi Findkos untuk pencarian indekost yang sekarang tidak hanya difokuskan untuk daerah Kukel saja tapi sudah menjangkau Beji, Kukusan, Pondok Cina dan Margonda. Pengguna juga dapat melakukan sorting dan filtering untuk memudahkan pencarian indekost yang sesuai dengan keinginan pengguna. Aplikasi FindKos pun juga menyediakan fitur kosan of the month, recent kosan dan rincian fasilitas yang disediakan oleh pemiliki indekost. Dibandingkan dengan aplikasi pencarian indekost lainnya, aplikasi FindKos memiliki kelebihan lain yaitu adanya fitur petunjuk rute untuk mencapai lokasi indekost yang dituju. Dari sejumlah data yang diperoleh tersebut, maka dibuat aplikasi pencarian indekost Findkos berbasis iOS untuk membantu para pengguna iPhone dalam mencari indekost yang diiinginkan di daerah Depok terutama bagi mahasiswa.

\section{Tinjauan Pustaka}

\section{A. Sistem Informasi Geografis (SIG)}

SIG atau Geographic Information System (GIS) adalah sebuah sistem yang didesain untuk menangkap, menyimpan, memanipulasi, menganalisa, mengatur dan menampilkan seluruh jenis data geografis. SIG tidak lepas dari data spasial, yang merupakan sebuah data yang mengacu pada posisi, obyek dan hubungan dalam ruang bumi. Data spasial merupakan salah satu item dari informasi di mana di dalamnya terdapat informasi mengenai bumi termasuk permukaan bumi, di bawah permukaan bumi, perairan, kelautan dan bawah atmosfer.[1] SIG merepresentasikan real world, yang merupakan sebuah cara bagaimana SIG mengubah bentuk fisik sebuah dunia menggunakan model menjadi sebuah sistem informasi geografis yang dapat disimpan, dimanipulasi, diproses dan dipresentasikan dengan data spasial yang terbagi atas dua model data yaitu model data raster dan model data vektor. Dalam data vektor bumi direpresentasikan sebagai suatu mosaik yang terdiri atas garis atau arc/line, polygon atau daerah yang dibatasi oleh garis yang berawal dan berakhir pada titik yang sama, titik atau point dan nodes yang merupakan titik perpotongan antara dua buah garis. Sedangkan untuk data raster adalah data yang dihasilkan dari sistem penginderaan jauh. Pada data raster, obyek geografis direpresentasikan sebagai struktur sel grid yang disebut dengan pixel dan resolusinya tergantung pada ukuran pixel-nya. Kedua data tersebut memiliki karakteristik yang berbeda, selain itu dalam pemanfaatannya tergantung dari masukan data dan hasil akhir yang akan dihasilkan.

\section{B. Sistem Informasi iPhone}

iPhone Operating System atau yang sekarang dikenal sebagai iOS adalah sistem operasi mobile yang dikembangkan dan didistribusikan oleh Apple Inc. Sistem operasi ini pertama kali diluncurkan tahun 2007 untuk iPhone dan iPod Touch dan telah dikembangkan untuk mendukung perangkat Apple lainnya seperti iPad dan Apple TV. Berbeda dengan pesaingnya seperti Windows Phone dan Android, Apple tidak melisensikan iOS untuk dipasang di ponsel pintar non-Apple.[2] Antarmuka pengguna iOS didasarkan pada konsep manipulasi langsung menggunakan gerakan multi sentuh. Elemen antarmukanya meliputi slider, switch dan tombol. Interaksi dengan iOS ini mencakup gerakan seperti geser, sentuh, jepit dan jepit buka, masing-masing memiliki arti sendiri dalam konteks sistem operasi Iphone dan antarmuka multi sentuhnya. iOS diturunkan dari OS X, yang memiliki fondasi Darwin dank arena itu iOS merupakan sistem operasi Unix. iOS adalah versi bergerak dari sistem operasi OS X yang dipakai di komputer-komputer Apple. Pada iOS, terdapat empat lapisan abstraksi yaitu Core OS, Core Services, Media dan Cocoa Touch. [3]

\section{Application Programming Interface (API)}

API adalah sekumpulan perintah, fungsi, dan protokol yang dapat digunakan oleh programmer saat membangun perangkat lunak untuk sistem operasi tertentu. API memungkinkan programmer untuk menggunakan fungsi standar untuk berinteraksi dengan sistem operasi lain. Dalam API terdapat fungsi-fungsi/perintah-perintah untuk menggantikan bahasa yang digunakan dalam system calls dengan bahasa yang lebih terstruktur dan mudah dimengerti oleh programmer. Fungsi yang dibuat dengan menggunakan API tersebut kemudian akan memanggil system calls sesuai dengan sistem operasinya.[4]

\section{Google Maps API}

Google juga menyediakan layanan Google Maps API yang memungkinkan para developer untuk mengintegrasikan Google Maps ke dalam website masing - masing dengan menambahkan data 
point sendiri. Aplikasi Google Maps dapat muncul di website dengan menggunakan API key, yang merupakan kode unik yang di-generate oleh Google untuk suatu website, agar server Google Maps dapat mengenali.

\section{PERANCANGAN DAN REALISASI}

\section{A. Perancangan Program Aplikasi}

1) Analisis Kebutuhan Sistem

Berdasarkan metode prototipe yang diterapkan dalam pengembangan sistem ini, langkah pertama yang harus dilakukan adalah melakukan analisis kebutuhan sistem. Analisis kebutuhan sistem merupakan kegiatan penguraian suatu sistem informasi ke dalam bagian atau komponen komputer yang bertujuan untuk mengidentifikasi serta mengevaluasi masalah-masalah yang muncul, hambatan-hambatan yang akan mungkin terjadi dan kebutuhan- kebutuhan yang diharapkan sehingga mengarah kepada solusi untuk perbaikan maupun pengembangan ke arah yang lebih baik dan sesuai dengan kebutuhan serta perkembangan teknologi. Adapun tahapan-tahapan yang ada pada analisa sistem ini meliputi: analisis masalah, kebutuhan non fungsional dan kebutuhan fungsional. [5]

\section{2) Deskprisi Aplikasi}

Seperti yang sudah dijelaskan sebelumnya, bahwa aplikasi Findkos merupakan aplikasi pencarian indekost dengan menggunakan Google Maps API dan memanfaatkan elemen yang terdapat dalam Google Maps API yaitu polyline dan direction untuk menggambarkan garis dari lokasi pengguna sampai ke alamat indekost yang dituju dan memberikan arahan berupa navigasi [4]. Terdapat 2 aktor yang dapat menjalankan aplikasi berbasis iOS ini, yaitu pengguna sebagai member, dimana pengguna ini sudah memiliki akun pada aplikasi Findkos sehingga memiliki hak akses untuk menjalankan seluruh fitur pada aplikasi Findkos. Aktor kedua adalah pengguna sebagai guest, dimana pengguna ini hanya dapat menjalankan beberapa fitur dalam Findkos seperti melihat detail indekost tanpa mendapatkan petunjuk arah menuju lokasi indekost dan mencari indekost.

\section{3) Cara Kerja Aplikasi}

Seperti yang telah dijelaskan sebelumnya, bahwa untuk menjalankan aplikasi secara keseluruhan, pengguna harus melakukan login terlebih dahulu. START menampilkan halaman awal Masuk dengan login form? Melakukan proses login Masuk dengan login Facebook? Melakukan proses login Facebook Daftar sebagai user? Melakukan proses pendaftaraan Berhasil? Berhasil? Menampilkan halaman utama N N Y Y Y N Y N Y Masuk tanpa login Berhasil? N Y N Pengguna memilih menu mencari indekos Menampilkan maps
Pengguna memilih salah satu indekos Menampilkan halaman detail indekos Pengguna memilih untuk menunjukkan rute Menampilkan map dan direction END.

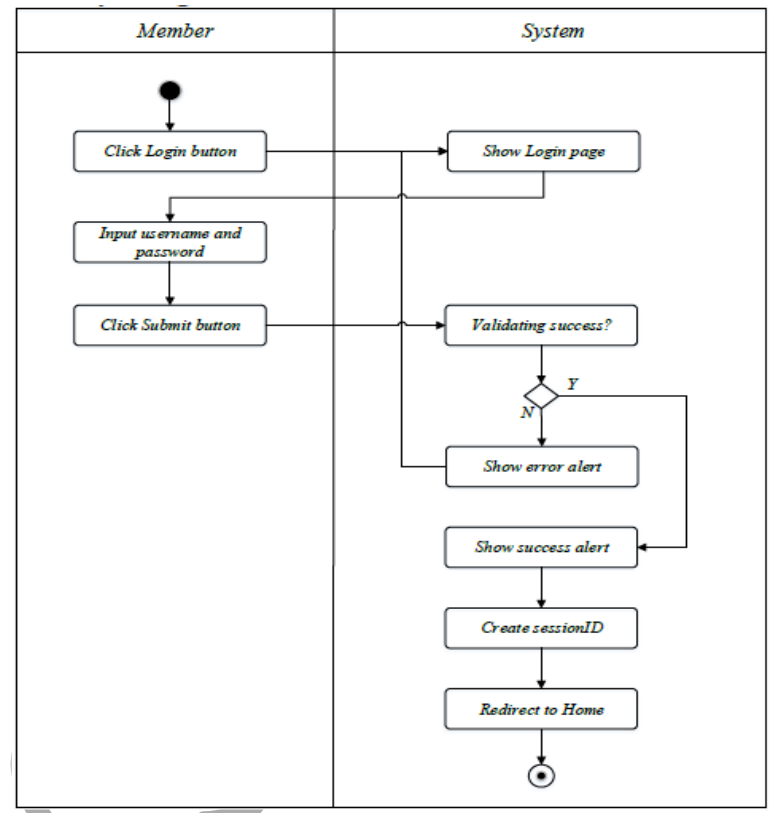

Gambar 2. Activity Diagram Login By Email

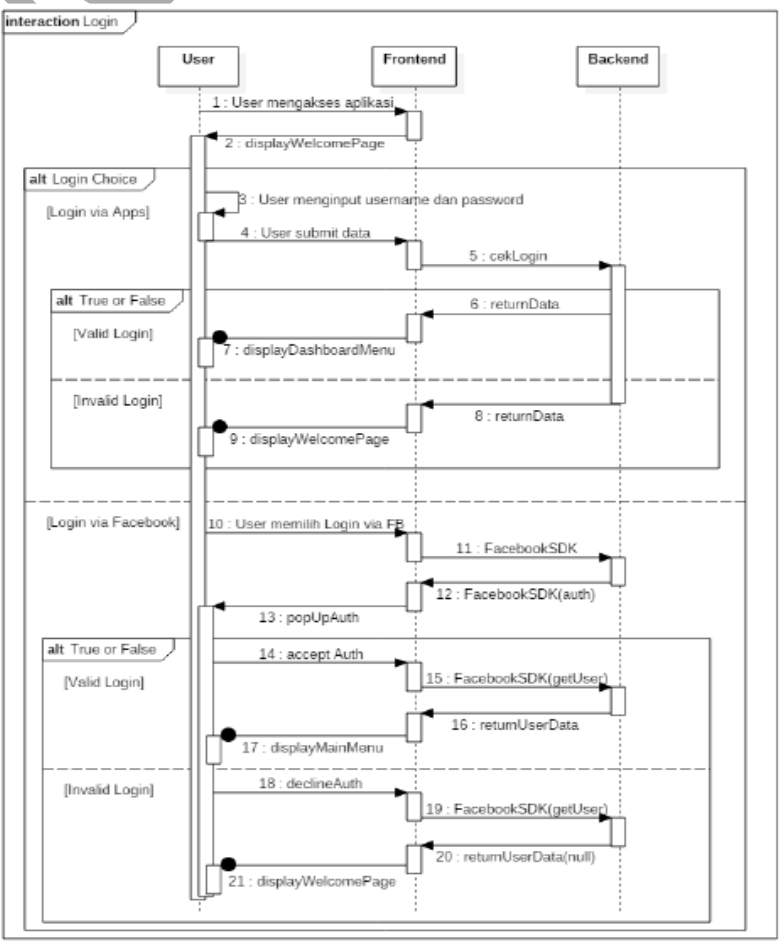

Gambar 3. Sequence Diagram

\section{Deployment Diagram}

Deployment diagram merupakan gambaran proses-proses berbeda pada suatu sistem yang berjalan dan bagaimana relasi di dalamnya. Pada aplikasi FindKos, deployement diagram ini melalui 
3 proses, yaitu satu buah server yang didalamnya terdiri dari Apache dan database yang berfungsi untuk menyimpan data-data yang digunakan dalam aplikasi FindKos, Facebook SDK yang digunakan pengguna untuk melakukan login dan iPhone sebagai device.

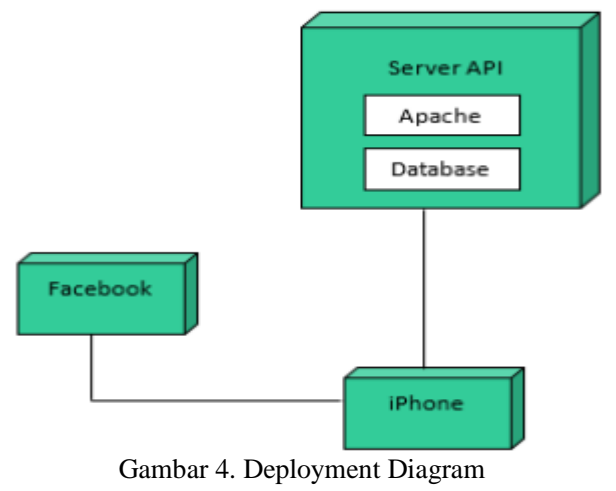

\section{B. Realisasi Program Aplikasi}

Tahap ketiga dari metode prototype adalah pembuatan perangkat prototype atau realisasi program aplikasi. Realisasi program aplikasi ini meliputi hasil dari pembuatan sistem yang telah dirancang dan dijelaskan pada subbab sebelumnya. Berikut ini merupakan hasil tampilan dari aplikasi FindKos.

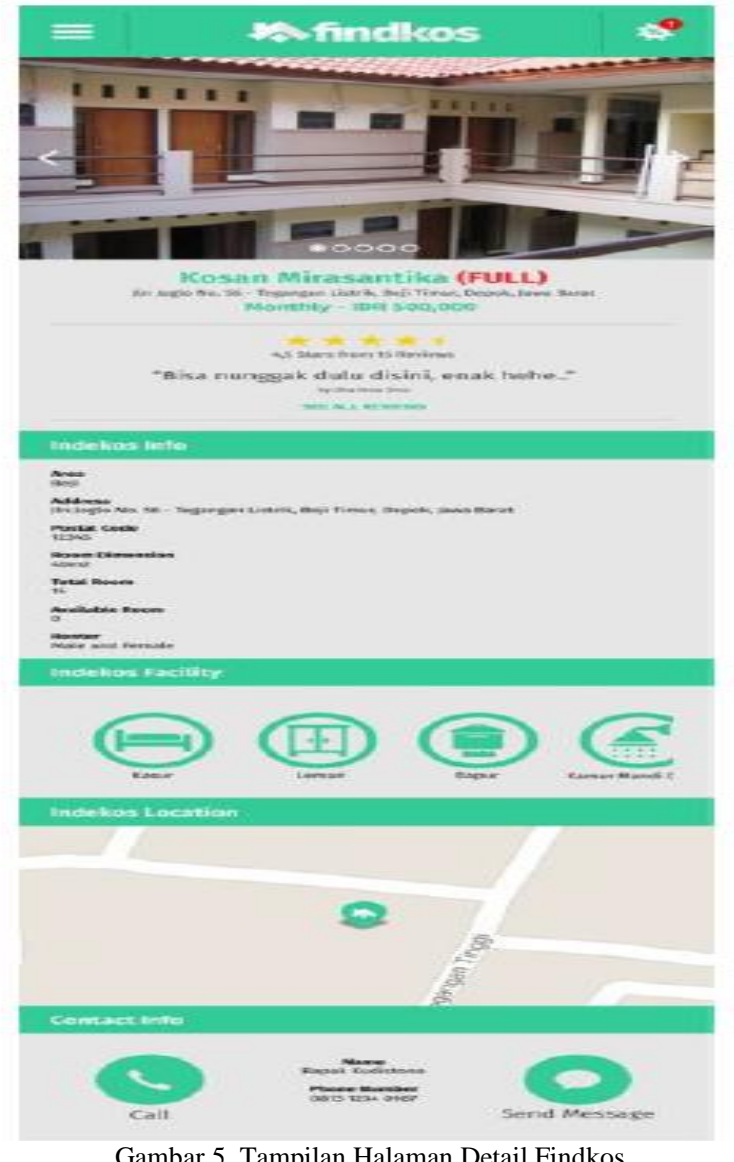

Gambar 5. Tampilan Halaman Detail Findkos

\section{PEMBAHASAN}

\section{A. Pengujian}

1) Deskripsi Pengujian

Setelah aplikasi selesai dibuat, maka tahapan selanjutnya yang harus dilakukan adalah pengujian aplikasi. Pengujian dilakukan untuk menjamin kualitas dan juga mengetahui kelemahan dari aplikasi yang sudah dibuat sebelumnya. Tujuan dari tahapan pengujian ini adalah untuk menjamin bahwa aplikasi yang sudah dibuat memiliki kualitas yang handal, yaitu mampu memenuhi kebutuhan pengguna serta menangani kemungkinan kesalahan pemasukan data oleh pengguna.

\section{2) Prosedur Pengujian}

Pengujian telah dilakukan dengan menggunakan pengujian alpha dan pengujian beta. Pengujian alpha menggunakan metode pengujian black box yang merupakan pengujian yang berfokus pada cara kerja atau fungsional aplikasi yang dibuat. Proses pengujian akan dilakukan terhadap semua kebutuhan fungsional yang dirancang pada tahap perancangan aplikasi. Cara pengujian yang dilakukan yaitu dengan menjalankan aplikasi Findkos dengan memasukkan data dan melihat apakah proses yang dihasilkan sudah sesuai dengan kebutuhan pengguna atau tidak. Pengujian dilakukan dengan memasukkan beberapa data masukan dengan kasus yang berbeda dan melakukan pengamatan yang terjadi pada item uji. Pengujian beta menggunakan kuesioner untuk mengetahui tanggapan pengguna terhadap aplikasi Findkos. Pengujian beta dilakukan pada berbagai operating system iPhone dengan minimal OS yaitu iOS 7 .

\section{B. Analisa Data/Evaluasi}

Berdasarkan hasil pengujian alpha, didapatkan hasil sebagai berikut :

a) Analisa Modul Sign Up

Pada modul sign up ini menggambar proses pendaftaran yang dilakukan oleh pengguna baru untuk memperoleh hak akses sehingga dapat menjalankan seluruh fitur yang terdapat pada aplikasi FindKos. Berdasarkan hasil yang diperoleh dari pengujian pada modul sign up, pengguna dapat memasukkan data sesuai ketentuan pada form sign up dan sistem dapat menampilkan pesan peringatan jika terdapat data yang tidak sesuai dengan ketentuan. Apabila pengguna tidak memasukkan foto profil, maka sistem akan mencantumkan foto default sesuai dengan jenis kelamin yang dipilih, sehingga pengguna tetap dpat mendaftrakan dirinya pada aplikasi FindKos. Setelah proses sign up berhasil, pengguna akan mendapatkan pesan berhasil dan diarahkan ke halaman Home untuk dapat menjalankan seluruh fitur yang terdapat pada aplikasi. 
b) Analisa Login

Pada modul login ini, aplikasi FindKos menyediakan 2 pilihan yaitu login dengan menggunakan akun FindKos yang telah didaftarkan dan login dengan menggunakan akun Facebook, pengguna perlu memasukkan email dan password, dan melakukan perizinan pengambilan data dari akun Facebook. Apabila pengguna tidak mengizinkan, maka pengguna tidak dapat menjalankan aplikasi FindKos dan sistem memberikan pesan peringatan bahwa pengguna tidak dapat menjalankan aplikasi FindKos. Namun apabila pengguna mengizinkan, maka sistem mengarahkan pengguna ke halaman Home.

c) Analisa Modul Forgot Password

Pada modul forgot password, pengguna dapat melakukan reset password dengan memasukkan email yang didaftarkan. Modul ini berjalan sesuai harapan, apabila pengguna memasukkan email dengan benar, maka sistem akan mengirimkan tautan untuk mengganti password. Namun jika pengguna salah memasukkan email, sistem akan memberikan pesan peringatan

d) Analisa Modul Navigation Bar

Modul Navigation Bar adalah modul yang hanya dapat dijlankan oleh pengguna yang berperan sebagai member atau yang telah melakukan login. Terdapat fungsi validasi yang dapat memeriksa apakah pengguna tersebut sudah memiliki userID. Apabila data yang dibaca sistem pengguna tidak memiliki userID maka sistem memberikan pesan peringatan untuk melakukan login. Namun jika sudah memiliki userID, pengguna dapat membuka halaman navigation bar. Pada modul ini terdapat beberapa submodule yaitu home, my profile. Request a kosan, settings, help, and feedback dan about findkos.

e) Analisa Modul list Indekos

Modul list Indekos merupakan modul untuk menampilkan daftar indekos sesuai dengan hasil pencarian fast filter yang juga merupakan tampilan lain dari halaman maps view. Fungsi ini sudah berjana dengan baik seperti membedakan warna panah yang terdapat pada halaman list view. Apabila sistem menampilkan data indekos yang dapat ditempati oleh wanita maupun pria, tanda panah berwarna hijau, sedangkan jika hanya diperuntukkan untuk wanita pada list berwarna merah, dan jika hanya diperuntukkan untuk laki-laki saja, pada halaman list menampilkan warna biru. Pada modul ini terdapat 3 sub modul, yaitu search, short, dan filter dengan hasil pencarian ditampilkan pada halaman list view.[6] Untuk sub modul search berfungsi dengan baik, termasuk jika pengguna memasukkan nama indekost dengan spasi, dan jika nama indekos yang diketik sudah terdapat pada database, maka sistem akan menampilkan daftar indekos yang dicari sesuai dengan kata kuncinya, namun bila tidak tersedia sistem akan menampilkan peringatan data tidak tersedia. Dalam sub modul short, pengguna dapat mencari indekos berdasarkan kategori yang tersedia, fungsi ini sudah berjalan dengan baik karena data yang ditampilkan sesuain dengan data yang terdapat pada database. Dan untuk sub modul filter, pengguna dapat mencari indekos sesuai dengan jenis kelamin atau area atau fasilitas yang diinginkan serta range harga. Fungsi ini berjalan dengan baik, karena dapat menampilkan data sesuai dengan data yang diinputkan.[6]

f) Analisa Modul Detail Indekos

Pada modul detail Indekos terdapat fungsi validasi seperti pada modul navigation bar. Apabila data pengguna yang dikirimkan sistem tidak memiliki userID, maka pengguna tersebut (guest) hanya dapat melihat tanpa menjalankan fitur review, direction, call, dan sms. Namun apabila pengguna sudah memiliki userID maka pengguna tersebut sudah dapat menjalankan fitur telepon, sms, pesan singkat secara otomatis, untuk menghubungi pemilik indekos, melihat review dan komentar serta memberikan review dan komentar terhadap indekos yang dipilih. Pengguna juga dapat menjalankan fitur direction yang memberikan petunjuk rute untuk dapat mencapai lokasi indekos yang dipilih dengan mengizinkan sistem findkos mendeteksi lokasi pengguna berdasarkan Global Positioning System (GPS).

\section{Uji Validitas}

\section{Uji Validitas Kuisioner}

Pengujian ini untuk mengukur tingkat validitas pertanyaan dan variabel yang diukur, menggunakan kuesioner. Kuisioner mengintrepetasikan hasil user dalam menggunakan aplikasi FindKos ini. Cara analisisnya dengan cara menghitung koefisien korelasi antara masing-masing nilai pada nomor pertanyaan dengan nilai total dari nomor pertanyaan tersebut. Selanjutnya koefisien korelasi yang diperoleh $r$ masih harus diuji signifikansinya dengan membandingkannya dengan $r$ tabel. Item kuesioner dikatakan valid, jika $\mathbf{r}$ hitung daripada nilai $\mathbf{r}$ tabel. Dengan jumlah responden $\mathrm{N}=30$, dan derajat bebas $\mathrm{df}=\mathrm{N}-2$, maka $\mathrm{df}=28$. Dalam tabel $\mathrm{r}$ product moment pada signifikasi $5 \%$, didapatkan nilai df 28 adalah 0.3610. Pada kasus ini jika dibandingkan dengan kelima nilai rhitung rtabel yang secara tidak langsung menyatakan bahwa seluruh data kuesioner bersifat valid. [7]

\section{Uji Reliabilitas Kuisioner}

Setelah semua pertanyaan valid semua, analisis dilanjutkan dengan uji reliabilitas. Untuk mengetahui reliabilitas adalah dengan 
membandingkan nilai $r$ hasil dengan $r$ tabel. Dalam uji reliabilitas sebagai nilai $r$ hasil adalah nilai "Cronbach's Alpha". Ketentuannya bila $\mathbf{r}$ Alpha > r tabel, maka pertanyaan tersebut reliabel. Pengujian reliabilitas instrumen dengan rentang skor antara 1-5 menggunakan rumus Cronbach's Alpha, dengan rumus sebagai berikut :

$$
r_{11}=\left(\frac{k}{k-1}\right)\left(1-\frac{\sum a b^{2}}{a_{1}^{2}}\right)
$$

Keterangan :

$\mathrm{r}_{11}=$ reabilitas instrument

$\mathrm{k}$ = banyaknya butir pertanyaan

= Jumlah varians butir tiap pertanyaan

$=$ varians total

Keputusan pengujian reliabilitas instrumen sebagai berikut :

1. Instrumen dikatakan reliabel jika rhitung > rtabel

2. Instrumen dikatakan tidak reliabel jika rhitung $<$ rtabel

Sesuai dengan didapatkan angka reabilitas sebesar 0.397679 dan lebih besar $r$ tabel untuk df perhitungan rumus, maka kuesioner penelitian telah reliabel sesuai dengan uji reliabilitas.

\section{KESIMPULAN}

Aplikasi Findkos sudah dapat menampilkan informasi Indekos dengan jangkauan lokasi daerah Depok, yaitu Kukusan, Beji, Pondok Cina, dan Margonda. Pengembangan selanjutnya terdapat pemeliharaan aplikasi agar semakin user friendly terhadap penggunaannya, serta up to date.

\section{DAFTAR PUSTAKA}

[1] Effendi, F. R. 2013. Android Sistem Operasi pada Smartphone. Universitas Surabaya, Surabaya

[2] Nazruddin Syafaat. 2012. Android: Pemrograman Aplikasi Mobile Smartphone dan Tablet PC. Informatika, Bandung.

[3] C. Liua, Q. Zhua, K. A. Holroydb, and E. K. Seng, "Status and trends of mobile-health applications for iOS devices: A developer's perspective," Journal of Systems and Software, vol. 84, no. 11, pp. 2022-2033, Nov. 2011.

[4] Ikhwan, M. Pengukuran Kinerja Goodreads Application Programming Interface (Api) Pada Aplikasi Mobile Android. Jurnal Informatika Vol 2, No.2 Mei-Agustus 2011.

[5] M. Neuburg. 2013. IOS 7 Programing Fundamentals, R. Rachel, Ed. Sebastopol: O'Reilley.

[6] Pengembangan Aplikasi Sunda Berbasis Android Menggunakan Metode Rapid Application Development (Rad). Jurnal Algoritma. ISSN : 2302-7339, Vol. 10 No 01, 2013.

[7] Santi Widianti, Iwan Setiadi dan Herul Fitman Hermawan. 2013. Aplikasi Pengenalan Alat Musik Tradisiona Indonesia Berbasis Android. Jurnal Ilmiah KOMPUTASI, Volume 12 Nomor : 2, Desember 2013 ISSN : 1412-9434 